\title{
Symposium review: Greenhouse gas emissions from liquid dairy manure: Prediction and mitigation ${ }^{1}$
}

\author{
Søren O. Petersen ${ }^{2}$ \\ Department of Agroecology, Aarhus University, Blichers allé 20, 8830 Tjele, Denmark
}

\begin{abstract}
The handling and use of manure on livestock farms contributes to emissions of the greenhouse gases (GHG) $\mathrm{CH}_{4}$ and $\mathrm{N}_{2} \mathrm{O}$, especially with liquid manure management. Dairy farms are diverse with respect to manure management, with practices ranging from daily spreading to long-term storage for more efficient recycling of manure nutrients for crop production. Opportunities for GHG mitigation will depend on the baseline situation with respect to handling and storage, and therefore prediction and mitigation at the farm level requires a dynamic description of housing systems and storage conditions, and use of treatment technologies. Also, effects of treatment and handling on the properties of field-applied manure must be taken into account. Storage conditions and manure composition importantly define carbon and nitrogen transformations, and the resulting emissions of $\mathrm{CH}_{4}$ and $\mathrm{N}_{2} \mathrm{O}$, as well as $\mathrm{CO}_{2}$ and $\mathrm{NH}_{3}$, which are all important for the GHG balance. Currently, inventories for $\mathrm{CH}_{4}$ and $\mathrm{N}_{2} \mathrm{O}$ emissions from manure are based on emission factors for a limited number of production systems, together with average annual temperature, but the inherent uncertainty of this approach is a barrier toward prediction and mitigation. Although more representative emission factors may be determined at country level, this is both challenging and costly, and effects of management changes for GHG mitigation are not easily quantified. An empirical model of $\mathrm{CH}_{4}$ emissions during storage is discussed that is based on daily time steps, and a parameterization based on measurements. A distinction between emissions from manure in barns and outside storage facilities is important for assessing effects of treatment technologies, such as anaerobic digestion, where only posttreatment emissions are affected. Upon
\end{abstract}

\footnotetext{
Received June 7, 2017.

Accepted September 24, 2017.

${ }^{1}$ Presented as part of the Production, Management, and the Environment Symposium: Greenhouse Gas Emissions from Dairy Operations at the ADSA Annual Meeting in Pittsburgh, Pennsylvania, in June 2017.

${ }^{2}$ Corresponding author: sop@agro.au.dk
}

field application, manure and soil together define the equilibrium distribution of labile carbon and nitrogen between bulk soil and manure hotspots. This introduces heterogeneity with respect to potential for $\mathrm{N}_{2} \mathrm{O}$ emissions, which is not represented in existing prediction models. Manure treatment and management options for GHG mitigation are discussed with emphasis on effects on manure volatile solids and $\mathrm{N}$ availability. Anaerobic digestion and acidification represent treatment technologies that are relevant for GHG mitigation on dairy farms.

Key words: manure management, methane, nitrous oxide, volatile solids

\section{INTRODUCTION}

According to a recent life cycle analysis (Thoma et al., 2013a), the United States dairy sector is responsible for $1.9 \%$ of total national greenhouse gas (GHG) emissions, whereas globally this contribution is 3 to $5 \%$ (FAO, 2010). Main sources are $\mathrm{CH}_{4}$ emissions associated with enteric fermentation and manure management, and $\mathrm{N}_{2} \mathrm{O}$ emissions from feed and food production, which are therefore also key targets of efforts to quantify emissions and mitigation potentials (Henriksson et al., 2011; Thoma et al., 2013a).

Dairy production systems are extremely diverse with respect to manure management practices and environmental conditions (Sommer et al., 2009; Thoma et al., 2013b), and this will influence the effectiveness of GHG mitigation measures. For example, Sommer et al. (2009) showed that $\mathrm{CH}_{4}$ emissions from manure in 5 European countries were affected differently by several treatment technologies due to differences in management and storage temperature. Similarly, the 2 states in the United States with the largest dairy herds, California (CA) and Wisconsin (WI), are different with respect to both climate and manure management practices; a survey found that 50 to $67 \%$ of WI dairy farms spread manure year-round without storage, representing on average $45 \%$ of the manure volume (Turnquist et al., 2006 ), whereas this was the case on only 26 to $27 \%$ of CA dairy farms in a survey of 2 counties (Meyer et 
al., 2011). As a consequence, the potential for mitigating $\mathrm{CH}_{4}$ emissions during storage would be greater for CA dairy farms, whereas the potential for improved $\mathrm{N}$ use efficiency and, in turn, $\mathrm{N}_{2} \mathrm{O}$ mitigation would be greater for WI dairy farms. Effective mitigation strategies thus depend on an accurate description of on-farm conditions.

\section{Contributions from $\mathrm{CH}_{4}$ and $\mathrm{N}_{2} \mathrm{O}$}

Greenhouse gas emissions on dairy farms are dominated by $\mathrm{CH}_{4}$ and $\mathrm{N}_{2} \mathrm{O}$ (Chianese et al., 2009; Kristensen et al., 2011). Even in regions where the number of cows have declined, such as North America and Western Europe, a change toward liquid manure management and extended storage have increased emissions of both gases (Wightman and Woodbury, 2016). The global warming potential (GWP) of $\mathrm{CH}_{4}$ and $\mathrm{N}_{2} \mathrm{O}$ are normally considered for a time horizon of $100 \mathrm{yr}$, and current estimates of $\mathrm{GWP}_{100}$ for $\mathrm{CH}_{4}$ and $\mathrm{N}_{2} \mathrm{O}$ are, respectively, 34 and 298 times the $\mathrm{GWP}_{100}$ of $\mathrm{CO}_{2}$ (Myhre et al., 2013). However, $\mathrm{CH}_{4}$ has a half-life in the atmosphere of only 12 to $13 \mathrm{yr}$, and thus for a 20-yr time horizon, $\mathrm{GWP}_{20}$, the contribution of $\mathrm{CH}_{4}$ is 2.5 -fold higher at 86 , which increases the relevance of $\mathrm{CH}_{4}$ mitigation efforts to curb global warming in the short term.

Emissions of $\mathrm{N}_{2} \mathrm{O}$ are associated with $\mathrm{N}$ transformations via nitrification and denitrification under oxygen-limited conditions (Maharjan and Venterea, 2013). Sustained emissions require that aerobic and anaerobic environments exist in close proximity, which may be the case in organic crusts formed during liquid manure storage (Wood et al., 2012), and in solid manure (Webb et al., 2011). Upon field application, factors such as manure composition, application method and soil conditions together determine the potential for $\mathrm{N}_{2} \mathrm{O}$ emissions, but given the unpredictable effects of climate, effects of treatment and management can vary dramatically. A recent meta-analysis (Charles et al., 2017) found that liquid and solid organic residues (including manure) are characterized by $\mathrm{N}_{2} \mathrm{O}$ emissions that are, respectively, above and below the emission factor currently used by most countries. However, the analysis also found strong positive interactions with soil $\mathrm{N}$ status, clay content, and precipitation, indicating that defining local conditions, as for $\mathrm{CH}_{4}$, is critical for more accurate estimation of emissions.

Gaseous $\mathrm{N}$ losses through $\mathrm{NH}_{3}$, nitrogen oxides $\left(\mathrm{NO}_{\mathrm{x}}\right)$, and $\mathrm{N}_{2}$, and leaching losses mainly as $\mathrm{NO}_{3}{ }^{-}$, are quantitatively much more important than direct emissions of $\mathrm{N}_{2} \mathrm{O}$ (Venterea et al., 2012). Because both $\mathrm{NH}_{3}$ volatilization and $\mathrm{NO}_{3}{ }^{-}$leaching are indirect sources of $\mathrm{N}_{2} \mathrm{O}$, the prevention of these losses through better $\mathrm{N}$ use efficiency is an effective strategy for $\mathrm{N}_{2} \mathrm{O}$ mitigation.

\section{Objectives}

Predicting $\mathrm{CH}_{4}$ and $\mathrm{N}_{2} \mathrm{O}$ emissions from livestock farms is a significant challenge, and currently the uncertainty associated with emission estimates effectively prevents accountability, regulation, and mitigation. Several recent papers and meta analyses have reviewed GHG emissions from manure management and mitigation options (e.g., Hristov et al., 2011; Petersen et al., 2013a; Hou et al., 2015; Jayasundara et al., 2016). In this review, I will instead highlight selected aspects of manure treatment and management that research, from laboratory to practical scale, has shown to be of particular importance for gaseous emissions of carbon $\left(\mathrm{CH}_{4}, \mathrm{CO}_{2}\right)$ and nitrogen $\left(\mathrm{N}_{2} \mathrm{O}, \mathrm{NH}_{3}\right)$. The main emphasis will be on dairy production systems. In view of the many potential interactions between different management stages, the discussion will address both manure management on the farm and subsequent field application.

\section{DRIVERS OF GHG EMISSIONS FROM MANURE}

Gerber et al. (2011) reported that the shares of solid and liquid manure management on dairy farms in North America were, respectively, 31 and 36\%, whereas the corresponding numbers for Western Europe were 36 and $38 \%$. In many parts of the world, the share of liquid manure management is increasing due to intensification of livestock production (Bouwman et al., 2013) and due to recommendations to store manure to recycle manure nutrients for crop production (Oenema et al., 2011). Because the potential for $\mathrm{CH}_{4}$ production is estimated to be 4 - to 20 -fold higher with liquid compared with solid manure management depending on storage temperature (IPCC, 2006), it can be estimated that, for example, in Western Europe liquid manure accounts for $>90 \%$ of total $\mathrm{CH}_{4}$ emissions from solid and liquid storage. As stated above, the potential for $\mathrm{N}_{2} \mathrm{O}$ emissions after field application is also higher from liquid manure (Charles et al., 2017), and the focus of this review is therefore on liquid manure management. It should be noted, however, that recently introduced deep litter systems also may have a high potential for $\mathrm{CH}_{4}$ as well as $\mathrm{N}_{2} \mathrm{O}$ emissions (Barberg et al., 2007; Galama, 2011).

\section{Storage Environment}

An overview of livestock manure handling systems was presented by Sørensen et al. (2013). Collection 
inside barns may occur in deep or shallow pits, and excreta may be scraped or flushed, or exported by gravity flow, for outside storage. Outside storage can take place in a concrete tank or pond, or lagoon(s). Dairy farms rely on an in-house pit or outside storage, or both. In pits beneath slatted floors, a significant volume of manure may be maintained to enable mobilization of settling solids during export; a recent survey found that in Denmark the resulting hydraulic retention time (HRT) for cattle slurry was 30 to $40 \mathrm{~d}$ (Kai et al., 2015). Anaerobic lagoons are widely used in North America as a cost-effective method to stabilize effluents through biodegradation of organic matter and settling of solids, but due to the prolonged retention time and large surface area, the potential for $\mathrm{CH}_{4}$ and $\mathrm{NH}_{3}$ emissions is high compared with storage tanks (IPCC, 2006; McGinn et al., 2008). Depending on inbarn and outside storage temperatures, the retention time in barns and outside storage, and any treatment in between, can significantly influence the fate of manure organic matter and nutrients before land application.

A storage design parameter of potential importance for the GHG balance of manure management is surfaceto-volume ratio. It is well established that the loss of $\mathrm{N}$ via $\mathrm{NH}_{3}$ emission is high in the absence of a cover such as a natural crust, floating membrane, or roof structure on storages to restrict gas exchange (Sommer et al., 1993). However, C metabolism is also influenced by gas exchange across the manure-air interface because manure represents a sink for atmospheric $\mathrm{O}_{2}$. The flux of $\mathrm{O}_{2}$ is proportional to the concentration gradient across the diffusive boundary layer (Jørgensen and Revsbech, 1985; Hafner et al., 2017). Thus, with uncovered liquid manure the mass transfer of dissolved organic $\mathrm{C}$ to the surface through the effect of wind or convective heat transfer (Hafner et al., 2017) will result in steep dissolved organic $\mathrm{C}$ concentration gradients that enhance $\mathrm{O}_{2}$ consumption compared with storages with a synthetic membrane or natural crust cover, because here the diffusive boundary layer is much greater and mixing less. Because the end product of aerobic heterotrophic activity is $\mathrm{CO}_{2}$, processes at manure surfaces will influence the proportions of volatile solids (VS) lost as $\mathrm{CH}_{4}$ and $\mathrm{CO}_{2}$ (Møller et al., 2004). Furthermore, both $\mathrm{CO}_{2} / \mathrm{HCO}_{3}{ }^{-} / \mathrm{CO}_{3}{ }^{2-}$ and $\mathrm{NH}_{3} / \mathrm{NH}_{4}{ }^{+}$are important components of the buffer system of manure (Sommer and Husted, 1995), and $\mathrm{CO}_{2}$ emissions from manure can enhance $\mathrm{NH}_{3}$ emissions by raising $\mathrm{pH}$ at the manure-air interface (Hafner et al., 2017). The relative importance of processes at this interface will also depend on the degree of filling; the surface-to-volume ratio thus increases after manure removal for field application.

The presence of active methanogens is a precondition for $\mathrm{CH}_{4}$ emissions during storage, but methanogens in fresh excreta may not thrive in harsh liquid manure environments (Chen et al., 2008a), and this can delay the appearance of $\mathrm{CH}_{4}$ emissions for weeks or even months (Sommer et al., 2007). Adaptation is therefore required, or inoculation with methanogens from residual manure in the pit, which is already adapted to this environment. Flushing and emptying of manure pits or storage tanks have been shown to delay the onset of methanogenesis (e.g., Haeussermann et al., 2006), but under practical storage conditions this can be difficult to achieve. Recently, Baldé et al. (2016) reported that removal of sludge from concrete tanks on a dairy farm in autumn had no detectable effect on $\mathrm{CH}_{4}$ emissions during storage the following summer.

\section{Manure Volatile Solids}

Volatile solids in liquid cattle manure typically constitute 75 to $85 \%$ of TS, the rest being sand and minerals (Møller et al., 2002; Petersen et al., 2003). According to Møller et al. (2004), labile fractions (VFA, protein, lipids, degradable carbohydrate) constitute around $69 \%$ of VS in cattle manure, and $79 \%$ in finishing pig manure. Any bedding will add to the concentration of DM, whereas effects on VS concentration will depend on the material used, such as straw, sawdust, sand, or recycled manure solids, which differ with respect to $\mathrm{CH}_{4}$ production potential, but also animal welfare, cost, and labor (Møller et al., 2004; Zdanowicz et al., 2004). Møller et al. (2002) found that $50 \%$ of TS in cattle manure were degraded during $7 \mathrm{mo}$ of storage at $20^{\circ} \mathrm{C}$. Assuming that labile pools of manure OM were lost to a greater extent than more recalcitrant components, the potential is significant for loss of labile VS, and thus $\mathrm{CH}_{4}$ emissions, even within a few weeks of storage, which has implications for manure treatment and management.

During storage, organic particles may remain suspended, settle, or float to the surface to form a natural crust. Up-drift may be created by gas bubbles (consisting mainly of $\mathrm{CH}_{4}$ and $\mathrm{CO}_{2}$ ) derived from methanogenic activity, and crust formation on dairy cattle manure has been observed to coincide with the onset of $\mathrm{CH}_{4}$ emissions (Misselbrook et al., 2005c; Wood et al., 2012). Also, Misselbrook et al. (2005c) reported that a glucose-starch additive promoted crust formation. Buoyancy of a crust is further supported by pockets of gas beneath the crust, which are intermittently deflated through cracks, as observed by Duan et al. (2017) using an oxygen microsensor. Thus, crust formation is a product of both recalcitrant and labile manure OM.

Depending on weather conditions (rainfall, temperature), a variety of microbial populations may develop in surface crusts. The microbial community will include populations of $\mathrm{CH}_{4}$ oxidizing bacteria, or methano- 
trophs (e.g., Petersen et al., 2005; Duan et al., 2017). Their activity depends on both availability of substrates $\left(\mathrm{CH}_{4}, \mathrm{O}_{2}\right)$ and inhibitory effects of mineral $\mathrm{N}$, but recent evidence suggests that mainly the activity of so-called type 1 methanotrophs responds to elevated $\mathrm{CH}_{4}$ availability in aerated parts of the crust (Duan et al., 2017). However, at this time limited information is available about the importance of methanotrophic activity in surface crusts for $\mathrm{CH}_{4}$ emissions. Natural crusts on manure storages are also a potential source of $\mathrm{N}_{2} \mathrm{O}$; this will be discussed later.

\section{Manure Nitrogen}

Manure recycling for crop production can significantly reduce the need for imported fertilizers, although ensuring a balanced nutrient supply with respect to $\mathrm{N}, \mathrm{P}, \mathrm{K}$, and $\mathrm{S}$ can be difficult with manure alone. For dairy cattle manure a direct relationship exists between $\mathrm{N}$ intake and excretion (Kebreab et al., 2001). The N excreted is partly unavoidable losses associated with, for example, microbial cell walls and residual protein, and partly a variable fraction of excess $\mathrm{N}$ excreted mainly as urea in the urine (Petersen et al., 1998). Urea is rapidly hydrolyzed to form $\mathrm{NH}_{4}{ }^{+}$and $\mathrm{NH}_{3}$ (total ammoniacal N, TAN), whereas mineralization of organic $\mathrm{N}$ is slower and temperature dependent. Sommer et al. (2007) found that mineralization of organic $\mathrm{N}$ in liquid pig and cattle manure varied between 5 and $85 \%$ when stored at 10,15 , or $20^{\circ} \mathrm{C}$ for up to $200 \mathrm{~d}$. Mineralization of organic $\mathrm{N}$ will increase manure $\mathrm{N}$ availability and $\mathrm{pH}$ (Eriksen et al., 2012), and therefore also the potential for environmental loss of TAN through $\mathrm{NH}_{3}$ emission. Depending on length of storage and ambient temperature, effective recycling of $\mathrm{N}$ for crop production will require $\mathrm{NH}_{3}$ mitigation measures.

Upon field application, both particle size distribution and soil properties influence redistribution of manure constituents. Vadas (2006) found that around $80 \%$ of the DM in liquid dairy and swine manure applied on top of a fine-loamy soil was retained at the surface, whereas the $20 \%$ of manure solids entering the soil was predominantly recovered within $10 \mathrm{~mm}$ distance from the surface. This is in accordance with the distribution of dissolved organic $\mathrm{C}$ and $\mathrm{NH}_{4}{ }^{+}$observed in soil around cattle manure layers, that is, 2-dimensional manure hotspots, in laboratory setups (e.g., Petersen et al., 1996), suggesting that $\mathrm{C}$ and $\mathrm{N}$ transformations and $\mathrm{N}_{2} \mathrm{O}$ emissions are concentrated within a limited soil volume in close contact with manure after field application. The VS in manure has a high water retention capacity compared with mineral soil; exponential relationships between manure VS concentration and water retention were described by Petersen et al. (2003).

\section{PREDICTING GHG EMISSIONS FROM MANURE}

The need to use a transparent and consistent methodology for national GHG inventories is widely accepted, and the United Nations' Framework Convention on Climate Change has recommended the use of guidelines developed by the Intergovernmental Panel on Climate Change (IPCC). This methodology is based on annual emission factors defined for a limited number of production systems, but several studies have pointed out that quantifying farm-level emissions is problematic with a methodology that is insensitive to local management (Weiske et al., 2006; Schils et al., 2007; Crosson et al., 2011; VanderZaag et al., 2013). Hence, more dynamic, yet transparent and consistent, methods to estimate GHG sources and sinks are needed, as well as mitigation potentials of treatment and management. This section discusses challenges and opportunities in relation to prediction of $\mathrm{CH}_{4}$ and $\mathrm{N}_{2} \mathrm{O}$ emissions from manure.

\section{Controls of $\mathrm{CH}_{4}$ Emissions}

The IPCC methodology for estimating $\mathrm{CH}_{4}$ emissions from manure management recommends use of a socalled methane conversion factor (MCF) to represent local manure storage conditions (IPCC, 2006). Default $\mathrm{MCF}$ values are proposed for a range of production systems based on average annual temperature, although countries are recommended to develop national or regional MCF through measurements, if possible. An MCF value must account for timing and length of storage, manure composition, presence of inoculum with adapted methanogens from older manure, daily and seasonal temperature variations, and retention time in the barn (IPCC, 2006). With such a wide range of storage conditions to be represented by a single value, the uncertainty associated with MCF is necessarily high, and it is relevant to consider the scope for a more dynamic description of key drivers.

Time is a key variable because management decisions influence storage conditions on a daily basis, and storage time before/after manure treatment if applicable. Manure volume and retention time in barns and outside storage facilities are readily calculated by day knowing the number of animals and grazing periods, excretion rate, and timing of transfer from barn to outside storage. This information can then be used to define storage temperature with daily time steps, which is critical to account for regional and seasonal differences in temperature that may be significant. For example, the average annual temperature in Milwaukee, WI, varied moderately between 4.4 and $13.1^{\circ} \mathrm{C}$ in the period from 1981 to 2010, but average monthly temperature 
varied between -9.1 and $26.7^{\circ} \mathrm{C}$ (Prism Climate Group, 2017). Detailed information about local temperature is generally accessible and hence may support a better spatio-temporal resolution of $\mathrm{CH}_{4}$ emission estimates.

The greatest challenge in predicting $\mathrm{CH}_{4}$ emissions may be the documentation of $\mathrm{CH}_{4}$ production rates. Four contrasting manure materials (pig manure, cattle manure, fresh digestate, and aged digestate) were found to have very similar activation energies, $E_{a}$ (i.e., temperature sensitivity), of methanogenesis in the range of 5 to $37^{\circ} \mathrm{C}$ (Elsgaard et al., 2016), whereas actual $\mathrm{CH}_{4}$ production rates were very different (Figure 1). The latter was partly explained by the differences in origin and treatment, but in practice $\mathrm{CH}_{4}$ production potential also varies with feeding (Jayasundara et al., 2016), as well as age and storage temperature (Sommer et al., 2007), and storage environment (Barret et al., 2013). Across 90 individual manure samples from 4 storage tanks with either pig or dairy cattle manure, Barret et al. (2013) observed a negative effect of VFA (and positive effect of $\mathrm{pH}$ ), presumably because methanogens were inhibited by the acidification associated with VFA accumulation (Chen et al., 2008a). There was also inter-storage and temporal variability in methangenic community composition, and a lower potential for $\mathrm{CH}_{4}$ production near the surface in pig manure, but not dairy manure. Although a multiple linear regression equation was able to describe the observed $\mathrm{CH}_{4}$ emissions based on 16 microbiological and chemical manure characteristics, it was acknowledged that additional complexity is introduced under practical storage conditions (Barret et al., 2013). Notably, the average age of the manure in a storage, and hence the extent of VS degradation at the time of observation, is typically unknown. In accordance with this, a sensitivity analysis found that estimates of $\mathrm{CH}_{4}$ production rate in individual manure materials were much more sensitive to $\mathrm{CH}_{4}$ production potential, as represented by $\ln \mathrm{A}$ (see next section), than to temperature or VS composition (Petersen et al., 2016).

Aerobic degradation near the manure-air interface (Patni and Jui, 1987; Møller et al., 2004; Barret et al., 2013) further complicates the prediction of $\mathrm{CH}_{4}$ emissions, since the removal of labile VS in the manure via aerobic degradation to $\mathrm{CO}_{2}$ will change the balance between $\mathrm{CH}_{4}$ and $\mathrm{CO}_{2}$ associated with loss of VS during storage. Implications of aerobic degradation for $\mathrm{CH}_{4}$ emissions will be greater for a pond with a surface area of up to several hectares (Leytem et al., 2011) compared with slurry tanks of $20 \mathrm{~m}$ diameter (Baldé et al., 2016). Observations from practical and pilot-scale storage confirm that proportions of $\mathrm{CH}_{4}$ and $\mathrm{CO}_{2}$ emitted are highly variable. In a study of emissions from a slurry tank, Laguë et al. (2005) observed $\mathrm{CH}_{4}$-C/
$\left(\mathrm{CH}_{4}-\mathrm{C}+\mathrm{CO}_{2}-\mathrm{C}\right)$ ratios in 3 seasons that ranged from 0.36 to 0.45 , whereas these ratios for 2 earthen basins averaged 0.24 (no cover) and 0.06 (straw cover). Viguria et al. (2015) found proportions of $\mathrm{CH}_{4}$ in emissions from 2 lagoons during spring corresponding to 0.15 to 0.2 (range: 0.1 to 0.4). Sommer et al. (2007) compared $\mathrm{CH}_{4}-\mathrm{C} /\left(\mathrm{CH}_{4}-\mathrm{C}+\mathrm{CO}_{2}-\mathrm{C}\right)$ ratios of slurry during simulated pit storage at 10,15 , and $20^{\circ} \mathrm{C}$; whereas at $10^{\circ} \mathrm{C}$ the ratios were 0.1 to 0.3 , at $20^{\circ} \mathrm{C}$ the ratios for cattle slurry shifted during storage from 0.2 to 0.5 , and to 0.65 in pig slurry. For the data presented by Leytem et al. (2011), $\mathrm{CH}_{4}-\mathrm{C} /\left(\mathrm{CH}_{4}-\mathrm{C}+\mathrm{CO}_{2}-\mathrm{C}\right)$ ratios of emissions from a dairy wastewater pond in early May, late May, August, and October were, respectively, 0.08, 0.25, 0.38 , and 0.45 at temperatures of 5.0, 15.4, 20.8, and 15.3. The importance of methanogenesis may increase over time as a result of microbial adaptation or changes in the storage environment (Sommer et al., 2007; Barret et al., 2013), but will then, as mentioned above, be constrained by the remaining substrate.

\section{Estimating On-Farm $\mathrm{CH}_{4}$ Emissions from Manure}

A dynamic method is needed to accurately estimate $\mathrm{CH}_{4}$ emissions from manure management; some main drivers (retention time, storage temperature, and methanogenic potential) were discussed above. Production systems may be classified on the basis of housing and

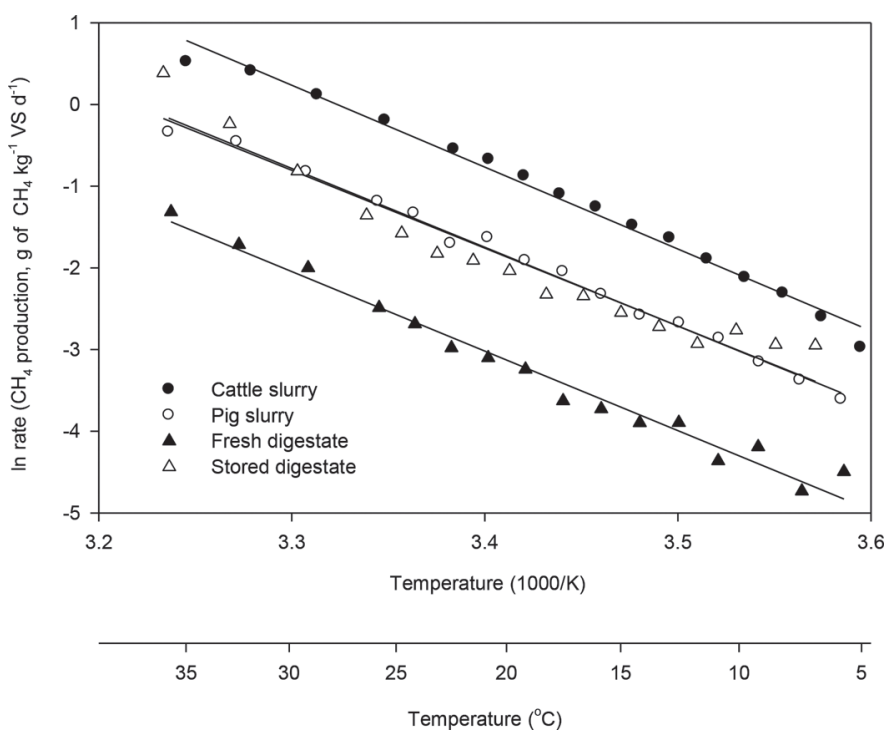

Figure 1. Arrhenius plots (ln rate versus inverse temperature, K) of the temperature response of $\mathrm{CH}_{4}$ production in 4 contrasting liquid manure materials for the temperature range of 5 to $37^{\circ} \mathrm{C}$. The manure materials were cattle slurry, pig slurry, fresh digestate from a thermophilic digester, and digestate from the same digester after several weeks of storage. The slopes of regression lines were not significantly different and averaged $81 \mathrm{~kJ} / \mathrm{mol}$. VS = volatile solids. Reproduced with permission from Elsgaard et al. (2016). 
storage design, whereas treatment and management practices define manure retention times and storage temperatures in barn and outside storage. Estimation of daily emissions is needed to analyze effects of storage conditions and management in detail. Models using daily time steps for manure management include the Integrated Farm Systems Model (Chianese et al., 2009) and Manure-DNDC (Li et al., 2012). Both models depend on external parameters; that is, the temperature relationship of Integrated Farm Systems Model was adopted from Sommer et al. (2004) who in turn based values on a compilation of data from storage experiments, whereas Manure-DNDC relies on a submodel developed for soil environments, and a constant redox potential of $-300 \mathrm{mV}$ is used ( $\mathrm{Li}$ et al., 2012). As an alternative approach, Petersen et al. (2016) proposed a method where estimation of $\mathrm{CH}_{4}$ emissions is based on an in vitro anaerobic assay of $\mathrm{CH}_{4}$ production rates in freshly collected samples when incubated at near-ambient temperature. Assuming this represents $\mathrm{CH}_{4}$ emissions from the bulk liquid phase, rate measurements were used to parameterize a simple algorithm relating $\mathrm{CH}_{4}$ emissions to temperature:

$$
F_{t}=\left(\mathrm{VS}_{\mathrm{d}}+0.01 \mathrm{VS}_{\mathrm{nd}}\right) e^{\left(\ln \mathrm{A}-\frac{E_{a}}{R T}\right)} .
$$

In this equation, originally proposed by Sommer et al. (2004), $F_{t}$ is $\mathrm{CH}_{4}$ production rate $\left(\mathrm{mg}\right.$ of $\mathrm{CH}_{4} / \mathrm{kg}$ of $\mathrm{VS} / \mathrm{h}) ; \mathrm{VS}_{\mathrm{d}}$ and $\mathrm{VS}_{\mathrm{nd}}(\mathrm{kg} / \mathrm{kg}$ of $\mathrm{VS})$ are degradable and recalcitrant ("nondegradable") manure organic matter; $E_{\mathrm{a}}$ is activation energy $[81,000 \mathrm{~J} / \mathrm{mol}$ (Elsgaard et al., 2016)] and $\ln \mathrm{A}$ represents the pre-exponential factor ( $\mathrm{g}$ of $\mathrm{CH}_{4} / \mathrm{kg}$ of VS per hour) of an Arrhenius equation describing temperature sensitivity. Finally, $R$ is the universal gas constant $R(8.314 \mathrm{~J} / \mathrm{K} / \mathrm{mol})$, and $T$ is the ambient temperature at sampling $(K)$. Sommer et al. (2004) calculated the $\mathrm{VS}_{\mathrm{d}}$ from the biochemical composition of fresh excreta, but this approach is not feasible with partly degraded manure collected from a storage facility or pit, and Petersen et al. (2016) instead used an aerobic incubation assay to estimate VS degradability. This parameter, as well as the scaling factor of 0.01 between $\mathrm{VS}_{\mathrm{d}}$ and $\mathrm{VS}_{\mathrm{nd}}$ degradability, require further documentation, but a sensitivity analysis showed that model results mainly depended on the term $\ln \mathrm{A}$ which represents the $\mathrm{CH}_{4}$ production potential. The value of $\ln \mathrm{A}$ can be estimated for the individual manure samples by rearrangement of Equation [1] once $F_{t}$ has been determined. Although the individual estimate of $\ln \mathrm{A}$ has little predictive power, a database of measurements for a given production system can provide an estimate and uncertainty range, the representativeness of which would improve as the database of system-specific $\mathrm{CH}_{4}$ production rates expands.

Prediction of $\mathrm{CH}_{4}$ emissions, however, also requires information about VS degradation during manure storage (Petersen et al., 2016). Existing models assume a constant ratio between $\mathrm{CH}_{4}$ and $\mathrm{CO}_{2}$ for estimation of VS loss (IPCC, 2006; Mangino et al., 2001; Sommer et al., 2004; Li et al., 2012), but as shown above this ratio is highly variable and may change with manure treatment and storage time. A separate assay would be needed to estimate $\mathrm{C}$ loss as $\mathrm{CH}_{4}$ and $\mathrm{CO}_{2}$ at the manure-air interface, and such an incubation system has yet to be developed. The method described thus requires further development, but has a potential for dynamic modeling of $\mathrm{CH}_{4}$ emissions and VS loss during manure storage with direct reference to experimental data, where information about total $\mathrm{C}$ loss can help constrain estimates of $\mathrm{VS}_{\mathrm{d}}$.

Daily emission estimates can be recalculated to an MCF value for reporting, or separate MCF values can be calculated for in-barn and outside storage (Mikkelsen et al., 2016). This is important if manure treatment takes place following export from the barn because then only posttreatment emissions are affected. By reducing uncertainties for individual sources, it would allow for more effective GHG mitigation.

\section{Controls of $\mathrm{N}_{2} \mathrm{O}$ Emissions}

Ammonia losses during manure management are a significant indirect source of $\mathrm{N}_{2} \mathrm{O}$ (Hristov et al., 2011). McGinn et al. (2008) found that $13 \%$ of TAN was lost from a lagoon with cattle manure during summer storage in Western Canada. They further reported that wind speed and surface temperature together explained $59 \%$ of the variability in $\mathrm{NH}_{3}$ emissions, and in accordance with this up to $35 \%$ of TAN may be lost in warmer climates (McGinn et al., 2008). Ammonia losses during manure storage can be reduced by around $80 \%$ with a cover in the form of a natural crust or synthetic membrane (Sommer et al., 1993; Miner et al., 2003). With a natural crust, however, the reduction of $\mathrm{NH}_{3}$ emissions may be accompanied by direct emissions of $\mathrm{N}_{2} \mathrm{O}$ produced around aerobic-anaerobic interfaces (Duan et al., 2017).

For liquid manure developing a natural crust, the IPCC (2006) guidelines recommend an $\mathrm{N}_{2} \mathrm{O}$ emission factor of $0.005 \mathrm{~kg}$ of $\mathrm{N}_{2} \mathrm{O}-\mathrm{N} / \mathrm{kg}$ of $\mathrm{N}$ stored, with an uncertainty range of 0.0025 to $0.01 \mathrm{~kg}$ of $\mathrm{N}_{2} \mathrm{O}-\mathrm{N} / \mathrm{kg}$ of N. Available results from pilot-scale data are mostly within this range (Jayasundara et al., 2016), but there is a need for documenting emissions at a practical scale, and to better understand what constrains this source. 
Typically crust formation is followed by a lag phase of several weeks before $\mathrm{N}_{2} \mathrm{O}$ is observed (Sommer et al., 2000; Wood et al., 2012; Petersen et al., 2013b), which indicates that conditions in the crust do not support nitrification and denitrification activity during this period. Sommer et al. (2000) found that temporal dynamics were related to the water balance of the crust (precipitation minus evapotranspiration), suggesting that initially crust wetness is the limiting factor, but interactions between microbial activities and the physical and chemical environment of the crust are not well characterized at present.

For field-applied manure, as for mineral $\mathrm{N}$ fertilizers, an emission factor of $0.01 \mathrm{~kg}$ of $\mathrm{N}_{2} \mathrm{O}-\mathrm{N} / \mathrm{kg}$ of $\mathrm{N}$ is recommended (IPCC, 2006). An increasing number of both experimental and model studies report that the relationship between $\mathrm{N}$ input and $\mathrm{N}_{2} \mathrm{O}$ emissions is exponential rather than linear (e.g., McSwiney and Robertson, 2005; Philibert et al., 2012), and it has been proposed that high emissions are mainly associated with conditions where $\mathrm{N}$ input exceeds crop demand (i.e., where mineral $\mathrm{N}$ accumulates in the soil). However, meta-analyses also indicate that the uncertainty of $\mathrm{N}_{2} \mathrm{O}$ emission estimates can be reduced by including aspects of management or soil characteristics (Shcherbak et al., 2014; Charles et al., 2017).

One source of variability, which has so far not been addressed in prediction models, is the spatial heterogeneity of manure in soil. The liquid phase of manure will partly infiltrate the soil in response to water potential gradients (Petersen et al., 2003), a process that is largely complete within $24 \mathrm{~h}$ (Misselbrook et al., 2005b). Temporally stable gradients in volumetric water content are established (Petersen et al., 2003), which therefore represent also the distribution of dissolved (and mostly labile) $\mathrm{C}$ and $\mathrm{N}$ shortly after manure application. The potential for partial reallocation of both $\mathrm{C}$ and $\mathrm{N}$ constituents is important for $\mathrm{N}_{2} \mathrm{O}$ emissions because turnover of components infiltrating the bulk soil takes place in an environment with a higher $\mathrm{O}_{2}$ availability than manure "hotspots" where both water content and $\mathrm{O}_{2}$ demand is much higher than in the surrounding soil (Petersen et al., 1996; Baral et al., 2016). It is probably important to acknowledge that $\mathrm{N}_{2} \mathrm{O}$ emissions associated with organic hotspots that are dominated by manure (or crop residues) follow different dynamics compared with $\mathrm{N}_{2} \mathrm{O}$ emissions from bulk soil where the potential for emissions depends mainly on bulk soil properties such as gas diffusivity (Balaine et al., 2013).

Manure application method will evidently influence the size distribution of manure hotspots, with direct injection, band-spreading, and broadcasting representing methods with increasing contact between manure and soil. Manure distribution in soil following applica- tion has, however, mainly been described for injection methods (Petersen et al., 2003; Rahman et al., 2004) and surface application (Misselbrook et al., 2005b).

\section{Estimating $\mathrm{N}_{2} \mathrm{O}$ Emissions After Field Application}

The IPCC methodology for estimating $\mathrm{N}_{2} \mathrm{O}$ emissions from field-applied manure is based on annual emission factors, where the default (Tier 1) emission factor is $0.01 \mathrm{~kg}$ of $\mathrm{N}_{2} \mathrm{O}-\mathrm{N} / \mathrm{kg}$ of $\mathrm{N}$. The associated uncertainty range of 0.003 to $0.3 \mathrm{~kg}$ of $\mathrm{N}_{2} \mathrm{O}-\mathrm{N} / \mathrm{kg}$ of $\mathrm{N}$ of the Tier 1 emission factor probably reflects inherent diversity of soil conditions that the emission factor is expected to represent because little improvement in precision was achieved by expanding the database (Stehfest and Bouwman, 2006). There is thus a pressing need for more informed estimates of $\mathrm{N}_{2} \mathrm{O}$ emissions from $\mathrm{N}$ applied to soil. Experimental determination of $\mathrm{N}_{2} \mathrm{O}$ emissions can provide Tier 2 emission factors at country level, although this requires a significant effort (e.g., Bell et al., 2015) and is not realistically done for all relevant combinations of $\mathrm{N}$ input and soil conditions. Dynamic models, referred to as Tier 3 in the IPCC terminology, have also been investigated for prediction of $\mathrm{N}_{2} \mathrm{O}$ emissions from soil, but data requirement for parameterization is high, and deviations in the reproduction of temporal dynamics (e.g., Li et al., 2012) suggest that underlying processes are not fully understood.

Chen et al. (2008b) reviewed several process-based models for estimating $\mathrm{N}_{2} \mathrm{O}$ emissions from soil, including NGAS-DAYCENT, DNDC, ecosys, NLOSS, Expert-N, WNMM, FASSET, and CERES-NOE. A common feature of these models is that they define soil layers assumed to be uniform with respect to physical, chemical, and microbiological characteristics. The application of liquid manure and other residues presents a challenge for such models insofar as individual constituents (water, $\mathrm{C}$ pools, $\mathrm{N}$ pools), and therefore labile $\mathrm{C}$ and $\mathrm{N}$ are in fact not evenly distributed within a given layer, but will be partly concentrated in manure-affected volumes that may be viewed as hotspots of intense $\mathrm{C}$ and $\mathrm{N}$ cycling. Size and distribution of manure hotspots will depend on application method and any subsequent tillage. Many studies have demonstrated how interactions between aerobic heterotrophic activity, nitrification, and denitrification in the gradient environment around such hotspots interact with soil conditions in determining the extent of denitrification and $\mathrm{N}_{2} \mathrm{O}$ emissions (Nielsen and Revsbech, 1994; Petersen et al., 1996; Markfoged et al., 2011; Baral et al., 2016). Presumably the surface-to-volume ratio of manure hotspots is critical for predicting $\mathrm{N}_{2} \mathrm{O}$ emissions, by determining the balance between aerobic and anaerobic degradation of labile C and N (Baral et al., 2016), and this could be 
the reason why models that distribute manure constituents uniformly throughout a 2-dimensional soil layer fail to reproduce the dynamics of observed emissions (Chen et al., 2008b).

The distribution of manure $\mathrm{C}$ and $\mathrm{N}$ will approach a new equilibrium distribution within $24 \mathrm{~h}$ after field application of liquid manure (Misselbrook et al., 2005b). One way to account for this heterogeneity could be to use this new distribution as boundary conditions for transformations of labile manure $\mathrm{C}$ and $\mathrm{N}$ (including mineral N) after field application. Bulk soil conditions in the relevant soil layer could then be assumed for manure $\mathrm{C}$ and $\mathrm{N}$ transformations of the fraction infiltrating the soil. In contrast, separate conditions would need to be defined for an environment representing manure hotspots, to account for the co-occurrence of elevated water content and $\mathrm{O}_{2}$ demand, and the coupling of nitrification and denitrification around aerobic-anaerobic interfaces (see Nielsen and Revsbech, 1994, and references therein). One requirement for this hypothetical model for manure distribution in soil is an estimate of the allocation of labile $\mathrm{C}$ and $\mathrm{N}$ between bulk soil and manure hotspots. An approach was proposed by Sommer et al. (2004) based on previously observed exponential relationships between water potential and VS in 22 manure materials including cattle manure, pig manure, and digestates:

$$
\mathrm{f}_{\mathrm{R}}=1-1 /(1+\mathrm{aVS}),
$$

and

$$
\mathrm{a}=0.063+1.33 \mathrm{e}^{77.8 \psi},
$$

where $f_{R}$ is the proportion of manure water retained by VS, $\psi(\mathrm{MPa})$ is soil water potential at the time of application, and a is a parameter defined by $\Psi$. Assuming that water retention in manure hotspots is a function of particulate VS (VS $\left.\mathrm{VI}_{\mathrm{nd}}, \mathrm{g} / 100 \mathrm{~g}\right)$ and a variable fraction $\left(f_{R}\right)$ of labile VS $\left(\mathrm{VS}_{\mathrm{d}}, \mathrm{g} / 100 \mathrm{~g}\right)$, that is, $\mathrm{VS}_{\text {hotspots }}=$ $V S_{n d}+f_{R} V S_{d}$, then $f_{R}$ also defines the fraction of $V_{d}$ (and labile N) retained in hotspots, which can be determined by iteration. This empirical approach requires further validation, but could be a starting point for attempts to integrate heterogeneity in simulations of manure $\mathrm{C}$ and $\mathrm{N}$ turnover in soil.

\section{MITIGATING GHG EMISSIONS FROM MANURE}

The previous sections have indicated that both particulate (recalcitrant) and dissolved (labile) VS are important determinants of both $\mathrm{CH}_{4}$ and $\mathrm{N}_{2} \mathrm{O}$ emissions from manure management and after field application.
During storage, labile $\mathrm{C}$ and $\mathrm{N}$ are sources of $\mathrm{CH}_{4}$ and $\mathrm{N}_{2} \mathrm{O}$ (in part via $\mathrm{NH}_{3}$ emissions), whereas particulate VS may restrict atmospheric emissions if a natural crust forms. Surface crusts are themselves a potential site of $\mathrm{CH}_{4}$ and $\mathrm{N}_{2} \mathrm{O}$ metabolism. Upon field application, the amount and composition of VS in manure are important controls of the redistribution of labile $\mathrm{C}$ and $\mathrm{N}$ which, together with soil properties, determine the potential for $\mathrm{N}_{2} \mathrm{O}$ emissions. In view of these and other mechanisms, by which manure VS can affect emissions, it may be useful to also discuss potential mitigation strategies in terms of their effect on manure VS composition or turnover.

\section{Feeding}

Jayasundara et al. (2016) presented a thorough review of relationships between cattle dietary changes and additives, and $\mathrm{CH}_{4}$ emissions. The most consistent effects have been seen for lipid supplements, where a regression analysis indicated that a 9 to $12 \%$ reduction is achievable, but it was stressed that such effects may be reciprocated by higher $\mathrm{CH}_{4}$ emissions from the manure, as exemplified by Hellwing et al. (2014). This negative interaction is compounded in warmer climates and stresses the need to consider GHG mitigation at farm level. Among additives, the most promising results have been with nitrate and 3-nitrooxypropanol, in some cases with $\mathrm{CH}_{4}$ mitigation effects of 30 to $60 \%$ (Jayasundara et al., 2016). For these additives, however, more research is needed to fully document implications for environment and animal health. Reducing the protein in DMI of dairy cows will also influence the $\mathrm{N}$ content and composition of excretal returns, by selectively reducing the amount of $\mathrm{N}$ excreted as urea in the urine. A reduction of urinary $\mathrm{N}$ can reduce $\mathrm{NH}_{3}$ losses (Petersen et al., 1998; Misselbrook et al., 2005a) and hence indirect $\mathrm{N}_{2} \mathrm{O}$ emissions.

\section{In-House Acidification}

Ammonia emissions from liquid manure can be reduced by commercially available technologies for acidification. The manure in pits below slatted floors is acidified by pumping manure to an external treatment tank for daily adjustment to $\mathrm{pH} 5.5$ with sulfuric acid $\left(\mathrm{H}_{2} \mathrm{SO}_{4}\right)$ in a strictly contained and automated process, or acidification can take place directly in storage tanks or during field application (Fangueiro et al., 2015). Acidification effectively reduces $\mathrm{NH}_{3}$ emissions from the liquid manure, but not from slats and soiled surfaces, and thus for cattle barns a reduction of $50 \%$ is acknowledged for regulatory purposes (http://www .vera-verification.eu/). 
Table 1. Reduction in $\mathrm{CH}_{4}$ emissions by anaerobic digestion (AD), and interaction with shorter hydraulic retention time (HRT) in the pit before digestion (Mikkelsen et al., 2016); model parameters are from Petersen et al. (2016)

\begin{tabular}{lccc}
\hline Item & $\begin{array}{c}\mathrm{kg} \text { of } \mathrm{CO}_{2} \mathrm{eq}^{1} / \mathrm{Mg} \\
\text { of slurry, cattle }\end{array}$ & $\begin{array}{c}\mathrm{kg} \text { of } \mathrm{CO}_{2} \text { eq/ } \\
\text { of slurry, pig }\end{array}$ & $\begin{array}{c}\mathrm{Gg} \text { of } \mathrm{CO}_{2} \text { eq/PJ } \\
\text { of energy }\end{array}$ \\
\hline Untreated & 19.25 & 62.25 & $\mathrm{NA}^{2}$ \\
$\mathrm{AD},{ }^{3}$ HRT of $20 \mathrm{~d}$ & -7.88 & -15.32 & -8.72 \\
$\mathrm{AD},{ }^{3}$ HRT of $7 \mathrm{~d}^{4}$ & -13.75 & -42.33 & -20.75 \\
\hline
\end{tabular}

${ }^{1}$ eq $=$ equivalent.

${ }^{2} \mathrm{NA}=$ not applicable.

${ }^{3}$ Digestate assumed to contain $58 \%$ cattle slurry and $42 \%$ pig slurry by volume, in accordance with national statistics for Denmark.

${ }^{4}$ Where possible.

Interestingly, storage experiments have also shown that $\mathrm{H}_{2} \mathrm{SO}_{4}$ addition inhibits $\mathrm{CH}_{4}$ emissions from manure during storage. For example, reductions of 67 to $87 \%$ (Petersen et al., 2012) and 61 to $75 \%$ (Misselbrook et al., 2016) were observed in experiments with cattle manure stored for up to 3 mo, indicating that a $60 \%$ reduction of $\mathrm{CH}_{4}$ emissions from manure management is realistic by in-house acidification. Petersen et al. (2012) also found significant $\mathrm{CH}_{4}$ mitigation by $\mathrm{SO}_{4}{ }^{2-}$ or methionine addition without $\mathrm{pH}$ change, and by acidification with an alternative acid, and it was speculated that different mechanisms contribute to inhibition of methanogenesis. Environmental issues to be considered with this technology are changes in the odor profile, and field application of $\mathrm{S}$ in excess of crop needs, because 5 to $6 \mathrm{~kg} / \mathrm{t}$ of $\mathrm{H}_{2} \mathrm{SO}_{4}$ is needed for acidification of cattle slurry (Danish Centre for Verification of Climate and Environmental Technologies, 2012).

\section{Anaerobic Digestion}

Anaerobic digestion of livestock manure has several environmental benefits, including $\mathrm{CH}_{4}$ and odor mitigation, and improved plant $\mathrm{N}$ availability (Massé et al., 2011). Anaerobic digestion (AD) technologies range from on-farm covers of pits or lagoons, with or without heating, to centralized reactors with heating and active mixing, and often organic co-digestates are included to boost gas production. According to Key and Sneeringer (2011), $60 \%$ of US dairy production takes place on farms where manure management systems allow $\mathrm{AD}$ treatment. Due to the moderate methanogenic potential of manure, profitability of $\mathrm{AD}$ is low, but it has been argued that environmental and societal benefits should also be taken into account (Yiridoe et al., 2009).

Manure can only be treated by AD following export from the barn, and therefore only posttreatment emissions are affected. Because VS degradation takes place also during the collection period, the in-barn HRT becomes critical for GHG mitigation (i.e., a shorter retention time in the pit before treatment can reduce $\mathrm{CH}_{4}$ emissions and VS loss during collection while also boosting biogas yields). Annual MCF are evidently not useful for evaluating scenarios with different retention times. Instead the method represented by Equation [1] could be applied, as exemplified in Table 1 (Mikkelsen et al., 2016). Here, $\mathrm{CH}_{4}$ mitigation by $\mathrm{AD}$ treatment of pig and cattle manure in Denmark was estimated for HRT in the barn of either 20 or $7 \mathrm{~d}$ before digestion. Increasing the frequency of export was in this example projected to increase the $\mathrm{CH}_{4}$ mitigation potential of AD 2- to 3-fold. The most recent Danish national inventory for agricultural GHG emissions estimated a $41 \%$ reduction of $\mathrm{CH}_{4}$ emissions by $\mathrm{AD}$ treatment of cattle manure using this approach (Nielsen et al., 2016).

\section{Cover on Storage Facilities}

It is well established that methanotrophs inhabit surface crusts on manure, and the 2006 IPCC guidelines assumed a $40 \%$ reduction of $\mathrm{CH}_{4}$ emissions due to this activity (IPCC, 2006). However, no strong support has been found for an effect of this magnitude, and if in fact $\mathrm{CH}_{4}$ escapes mainly via cracks, as discussed above, then $\mathrm{CH}_{4}$ availability in the crust could be limiting. It has been proposed that an additional cover on manure storages combined with a crust, and with passive or active ventilation to maintain elevated $\mathrm{CH}_{4}$ concentrations in the headspace, could enhance methanotrophic activity by increasing $\mathrm{CH}_{4}$ availability in the air above the crust (Petersen and Miller, 2006). The most recent evidence regarding methanotrophs in surface crusts, their requirements for $\mathrm{CH}_{4}$ and $\mathrm{O}_{2}$, and sensitivity toward mineral $\mathrm{N}$, indicates that there is indeed a potential for stimulating $\mathrm{CH}_{4}$ oxidation in well-established natural crusts through controlled ventilation which should be explored (Duan et al., 2017). Covers for slurry tanks of concrete or tarpaulin are already available for protec- 
tion against $\mathrm{NH}_{3}$ losses, and could be adopted together with surveillance or even active control of $\mathrm{O}_{2}$ and $\mathrm{CH}_{4}$ availability.

\section{Reducing Nitrogen Surplus}

Several opportunities for management and treatment have already been discussed that can increase the manure $\mathrm{N}$ use efficiency (dietary changes, shorter HRT, cover on storages, acidification, and AD), although in some cases mitigation measures must be combined to avoid negative interactions between stages of management with respect to $\mathrm{NH}_{3}$ emissions (Hutchings et al., 1996). Powell and Rotz (2015) discussed several strategies for mitigating $\mathrm{N}$ surplus in dairy production systems and concluded that in many cases both dietary $\mathrm{CP}$ intake and mineral fertilizer $\mathrm{N}$ can be reduced with little effect on productivity. Schils et al. (2006) reported a reduction of $\mathrm{N}$ surplus on Dutch dairy farms of $20 \%$, from 300 to $240 \mathrm{~kg}$ of N/ha, between 1990 and 1999 as a result of less mineral fertilizer $\mathrm{N}$ applied and fewer grazing days, but because more manure was collected and stored on the farm, emissions of $\mathrm{CH}_{4}$ increased. An overall reduction of GHG emissions of $6 \%$ was calculated, though with a potential for improvement by adopting mitigation measures against $\mathrm{CH}_{4}$ emissions during manure storage.

Nitrification inhibitors have a potential to reduce $\mathrm{N}_{2} \mathrm{O}$ emissions, as well as $\mathrm{N}$ leaching from manure and fertilizers, and the reduction may be as high as 40 to $50 \%$ according to some meta-analyses (e.g., Qiao et al., 2015). This is accompanied by positive trends in crop $\mathrm{N}$ uptake and $\mathrm{N}$ recovery, although for individual experiments these effects are often not statistically significant. This mitigation strategy certainly deserves attention, but to achieve GHG mitigation the $\mathrm{N}$ surplus should also be reduced to prevent that direct $\mathrm{N}_{2} \mathrm{O}$ emissions are replaced by indirect emissions. In documenting effects of nitrification inhibitors, it is important to acknowledge the great diversity of active compounds in terms of water solubility, volatility, and persistence in the soil environment (Subbarao et al., 2007), and to investigate potential side effects (Kong et al., 2016).

\section{Enteric Emissions vs. Manure Management}

The relative importance of enteric fermentation and manure as sources of $\mathrm{CH}_{4}$ emissions on dairy farms will depend on housing system, management, and storage conditions, including climate. In temperate regions the proportion of $\mathrm{CH}_{4}$ emissions from liquid manure management on dairy farms is typically 15 to $20 \%$ (Chianese et al., 2009; Kristensen et al., 2011). However, in warmer climates the relative importance of $\mathrm{CH}_{4}$ emis- sions from manure may be much greater. Thus, Owen and Silver (2015) reported that for US dairy farms the average proportion of $\mathrm{CH}_{4}$ from manure management in 2011 was $43 \%$, and in California as high as $54 \%$.

Referring to the numbers given in previous subsections for effects of mitigation strategies, the $\mathrm{CH}_{4}$ mitigation potential of dietary changes on dairy farms in temperate climates would be in the range of 7 to $10 \%$ (i.e., a $9-12 \%$ reduction of enteric emissions constituting 80 to $85 \%$ of total $\mathrm{CH}_{4}$ emissions on dairy farms), and this assumes any increase in $\mathrm{CH}_{4}$ emissions from manure is avoided. By comparison, the potential for mitigation of $\mathrm{CH}_{4}$ emissions from manure through in-barn acidification may be 9 to $12 \%$ in temperate climates, and by $\mathrm{AD}$ treatment the potential may be 6 to $8 \%$. Here, indirect effects on $\mathrm{NH}_{3}$ emissions and $\mathrm{N}$ use efficiency should also be estimated. In warmer climates the $\mathrm{CH}_{4}$ mitigation potential and relative importance of manure treatment technologies would be greater. Although uncertainties are present and further documentation is required for both dietary changes and manure treatment technologies, these estimated mitigation potentials do highlight the relevance of considering GHG mitigation for manure management.

\section{CONCLUSIONS}

The diversity of manure management practices on dairy farms is high, with intensification favoring liquid manure management. This trend increases the potential for both $\mathrm{CH}_{4}$ and $\mathrm{N}_{2} \mathrm{O}$ emissions, and the need for mitigation. The existing IPCC methodology for estimating emissions from manure is not well suited to describe management at the farm level, and effects of management changes or manure treatment are not easily quantified, which is also a barrier toward future regulation of emissions. Both recalcitrant and labile fractions of VS in liquid manure were shown to be important for $\mathrm{CH}_{4}$ and $\mathrm{N}_{2} \mathrm{O}$ emissions during storage and after field application. For accurate estimation of $\mathrm{CH}_{4}$ emissions from manure, and $\mathrm{CH}_{4}$ mitigation potentials, it is important to estimate VS loss during storage in barns and outside storages separately. Accounting for manure $\mathrm{N}$ availability in fertilizer plans is a precondition for effective $\mathrm{N}_{2} \mathrm{O}$ mitigation. Adoption of GHG estimation methods with a better representation of temporal and spatial variability may offer the flexibility needed to quantify effects of manure treatment and management, and mitigation potentials.

\section{ACKNOWLEDGMENTS}

I thank the 2 anonymous reviewers for many valuable comments and suggestions. Preparation of this paper 
was supported by funding from the Ministry of Environment and Food of Denmark to the Department of Agroecology, Aarhus University.

\section{REFERENCES}

Balaine, N., T. J. Clough, M. H. Beare, S. M. Thomas, E. D. Meenken, and J. G. Ross. 2013. Changes in relative gas diffusivity explain soil nitrous oxide flux dynamics. Soil Sci. Soc. Am. J. 77:1496-1505.

Baldé, H., A. C. VanderZaag, S. D. Burtt, R. J. Gordon, and R. L. Desjardins. 2016. Does fall removal of the dairy manure sludge in a storage tank reduce subsequent methane emissions? J. Environ. Qual. 45:2038-2043.

Baral, K. R., E. Arthur, J. E. Olesen, and S. O. Petersen. 2016. Predicting $\mathrm{N}_{2} \mathrm{O}$ emissions from manure properties and soil moisture: An incubation experiment. Soil Biol. Biochem. 97:112-120.

Barberg, A. E., M. I. Endres, J. A. Salfer, and J. K. Reneau. 2007. Performance and welfare of dairy cows in an alternative housing system in Minnesota. J. Dairy Sci. 90:1575-1583.

Barret, M., N. Gagnon, E. Topp, L. Masse, D. I. Massé, and G. Talbot. 2013. Physico-chemical characteristics and methanogen communities in swine and dairy manure storage tanks: Spatio-temporal variations and impact on methanogenic activity. Water Res. 47:737-746.

Bell, M. J., N. Winning, R. M. Rees, J. M. Cloy, K. Topp, L. Cardenas, N. Donovan, T. Scott, C. Webster, A. Whitmore, J. Williams, H. Balshaw, F. Paine, and D. Chadwick. 2015. Nitrous oxide emissions from fertilised UK arable soils: Quantification and mitigation. Agric. Ecosyst. Environ. 212:134-147.

Bouwman, L., K. K. Goldewijk, K. W. Van Der Hoek, A. H. W. Beusen, D. P. Van Vuuren, J. Willems, M. C. Rufino, and E. Stehfest. 2013. Exploring global changes in nitrogen and phosphorus cycles in agriculture induced by livestock production over the 1900-2050 period. Proc. Natl. Acad. Sci. USA 110:20882-20887.

Charles, A., P. Rochette, J. K. Whalen, D. A. Angers, M. H. Chantigny, and N. Bertrand. 2017. Global nitrous oxide emission factors from agricultural soils after addition of organic amendments: A meta-analysis. Agric. Ecosyst. Environ. 236:88-98.

Chen, D., Y. Li, P. Grace, and A. Mosier. 2008b. $\mathrm{N}_{2} \mathrm{O}$ emissions from agricultural lands: A synthesis of simulation approaches. Plant Soil 309:169-189.

Chen, Y., J. J. Cheng, and K. S. Creamer. 2008a. Inhibition of anaerobic digestion process: A review. Bioresour. Technol. 99:4044-4064.

Chianese, D. S., C. A. Rotz, and T. L. Richard. 2009. Whole-farm greenhouse gas emissions: A review with application to a Pennsylvania dairy farm. Appl. Eng. Agric. 25:431-442.

Crosson, P., L. Shalloo, D. O’Brien, G. J. Lanigan, P. A. Foley, T. M. Boland, and D. A. Kenny. 2011. A review of whole farm systems models of greenhouse gas emissions from beef and dairy cattle production systems. Anim. Feed Sci. Technol. 166-167:29-45.

Danish Centre for Verification of Climate and Environmental Technologies. 2012. Statement of Verification. Acidification of cattle slurry for reduced ammonia emission. Accessed Sep. 2, 2017. http://www .etv-denmark.com/files/agriculture/JH-Forsuring_Verification _Statement_Ver\%201-6.pdf.

Duan, Y. F., S. Reinsch, P. Ambus, L. Elsgaard, and S. O. Petersen. 2017. Methanotrophic activity in slurry surface crusts as influenced by $\mathrm{CH}_{4}, \mathrm{O}_{2}$, and inorganic N. J. Environ. Qual. In press.

Elsgaard, L., A. B. Olsen, and S. O. Petersen. 2016. Temperature response of methane production in liquid manure and co-digestates. Sci. Total Environ. 539:78-84

Eriksen, J., A. J. Andersen, H. V. Poulsen, A. P. S. Adamsen, and S. O. Petersen. 2012. Sulfur turnover and emissions during storage of cattle slurry: Effects of acidification and sulfur addition. J. Environ. Qual. 41:1633-1641.

Fangueiro, D., M. Hjorth, and F. Gioelli. 2015. Acidification of animal slurry-A review. J. Environ. Manage. 149:46-56.

FAO (Food and Agriculture Organization of the United Nations). 2010. Greenhouse gas emissions from the dairy sector. A life cycle assessment. Rome, Italy, 94 pp. Accessed Sep. 4, 2017. http://www .fao.org/docrep/012/k7930e/k7930e00.pdf.

Galama, P. 2011. Prospects for bedded pack barns for dairy cattle. Wageningen UR Livestock Research, Publ. No. 16, 74 pp. Accessed Sep. 4, 2017. http://www.vrijloopstallen.nl/documenten/ Prospects for bedded_pack barns_for_dairy cattle.pdf.

Gerber, P., T. Vellinga, C. Opio, and H. Steinfeld. 2011. Productivity gains and greenhouse gas emissions intensity in dairy systems. Livest. Sci. 139:100-108.

Haeussermann, A., E. Hartung, E. Gallmann, and T. Jungbluth. 2006. Influence of season, ventilation strategy, and slurry removal on methane emissions from pig houses. Agric. Ecosyst. Environ. 112:115-121.

Hafner, S. D., S. G. Sommer, V. Petersen, and R. Markfoged. 2017. Effects of carbon dioxide hydration kinetics and evaporative convection on $\mathrm{pH}$ profile development during interfacial mass transfer of ammonia and carbon dioxide. Heat Mass Transf. 53:1335-1342.

Hellwing, A. L. F., M. R. Weisbjerg, and H. B. Møller. 2014. Enteric and manure-derived methane emissions and biogas yield of slurry from dairy cows fed grass silage or maize silage with and without supplementation of rapeseed. Livest. Sci. 165:189-199.

Henriksson, M., A. Flysjö, C. Cederberg, and C. Swensson. 2011. Variation in carbon footprint of milk due to management differences between Swedish dairy farms. Animal 5:1474-1484.

Hou, Y., G. L. Velthof, and O. Oenema. 2015. Mitigation of ammonia, nitrous oxide and methane emissions from manure management chains: A meta-analysis and integrated assessment. Glob. Change Biol. 21:1293-1312.

Hristov, A. N., M. Hanigan, A. Cole, R. Todd, T. A. McAllister, P. M Ndegwa, and A. Rotz. 2011. Ammonia emissions from dairy farms and beef feedlots. Can. J. Anim. Sci. 91:1-35.

Hutchings, N. J., S. G. Sommer, and S. C. Jarvis. 1996. A model of ammonia volatilization from a grazing livestock farm. Atmos. Environ. 30:589-599.

IPCC. 2006. 2006 IPCC Guidelines for National Greenhouse Gas Inventories, Prepared by the National Greenhouse Gas Inventories Programme. H. S. Eggleston, L. Buendia, K. Miwa, T. Ngara, and K. Tanabe, ed. Published: IGES, Japan. Accessed Sep. 4, 2017. http://www.ipcc-nggip.iges.or.jp/public/2006gl/.

Jayasundara, S., J. A. D. Ranga Niroshan Appuhamy, E. Kebreab, and C. Wagner-Riddle. 2016. Methane and nitrous oxide emissions from Canadian dairy farms and mitigation options: An updated review. Can. J. Anim. Sci. 96:306-331.

Jørgensen, B. B., and N. P. Revsbech. 1985. Diffusive boundary layers and the oxygen uptake of sediments and detritus. Limnol. Oceanogr. 30:111-122.

Kai, P., T. Birkmose, and S. Petersen. 2015. Slurry volumes and estimated storage time of slurry in Danish livestock buildings. AgroTech Report Dec 2015, 32 pp. (in Danish). Accessed Sep. 4, 2017. https://ens.dk/ansvarsomraader/bioenergi/biogas-taskforce.

Kebreab, E., J. France, D. E. Beever, and A. R. Castillo. 2001. Nitrogen pollution by dairy cows and its mitigation by dietary manipulation. Nutr. Cycl. Agroecosyst. 60:275-285.

Key, N., and S. Sneeringer. 2011. Climate Change Policy and the Adoption of Methane Digesters on Livestock Operations. USDA Economic Research Report No. 111, 47 pp.

Kong, X., Y.-F. Duan, A. Schramm, J. Eriksen, and S. O. Petersen. 2016. 3,4-Dimethylpyrazole phosphate (DMPP) reduces activity of ammonia oxidizers without adverse effects on non-target soil microorganisms and functions. Appl. Soil Ecol. 105:67-75.

Kristensen, T., L. Mogensen, M. T. Knudsen, and J. E. Hermansen 2011. Effect of production system and farming strategy on greenhouse gas emissions from commercial dairy farms in a life cycle approach. Livest. Sci. 140:136-148.

Laguë, C., É. Gaudet, J. Agnew, and T. A. Fonstad. 2005. Greenhouse gas emissions from liquid swine manure storage facilities in Saskatchewan. Trans. ASAE 48:2289-2296.

Leytem, A. B., R. S. Dungan, D. L. Bjorneberg, and A. C. Koehn. 2011. Emissions of ammonia, methane, carbon dioxide, and nitrous oxide from dairy cattle housing and manure management systems. J. Environ. Qual. 40:1383-1394. 
Li, C., W. Salas, R. Zhang, C. Krauter, A. Rotz, and F. Mitloehner. 2012. Manure-DNDC: A biogeochemical process model for quantifying greenhouse gas and ammonia emissions from livestock manure systems. Nutr. Cycl. Agroecosyst. 93:163-200.

Maharjan, B., and R. T. Venterea. 2013. Nitrite intensity explains N management effects on $\mathrm{N}_{2} \mathrm{O}$ emissions in maize. Soil Biol. Biochem. 66:229-238.

Mangino, J., D. Bartram, and A. Brazy. 2001. Development of a methane conversion factor to estimate emissions from animal waste lagoons. US EPA 17th Annual Emission Inventory Conference, USEPA, Research Triangle Park, NC. 16-18 April 2002, Atlanta, GA. Accessed Sep. 4, 2017. https://www3.epa.gov/ttnchie1/ conference/ei11/ammonia/mangino.pdf.

Markfoged, R., L. P. Nielsen, T. Nyord, L. D. M. Ottosen, and N. P. Revsbech. 2011. Transient $\mathrm{N}_{2} \mathrm{O}$ accumulation and emission caused by $\mathrm{O}_{2}$ depletion in soil after liquid manure injection. Eur. J. Soil Sci. 62:541-550.

Massé, D. I., G. Talbot, and Y. Gilbert. 2011. On farm biogas production: A method to reduce GHG emissions and develop more sustainable livestock operations. Anim. Feed Sci. Technol. 166167:436-445

McGinn, S. M., T. Coates, T. K. Flesch, and B. Crenna. 2008. Ammonia emission from dairy cow manure stored in a lagoon over summer. Can. J. Soil Sci. 88:611-615.

McSwiney, C. P., and G. P. Robertson. 2005. Nonlinear response of $\mathrm{N}_{2} \mathrm{O}$ flux to incremental fertilizer addition in a continuous maize (Zea mays L.) cropping system. Glob. Change Biol. 11:1712-1719.

Meyer, D., P. L. Price, H. A. Rossow, N. Silva-del-Rio, B. L. Karle, P. H. Robinson, E. J. DePeters, and J. G. Fadel. 2011. Survey of dairy housing and manure management practices in California. J. Dairy Sci. 94:4744-4750.

Mikkelsen, M. H., R. Albrektsen, and S. Gyldenkærne. 2016. Consequences of biogas production for greehouse gas emissions within agriculture (Biogasproduktions konsekvenser for drivhusgasudledning i landbruget). Aarhus University, DCE-National Centre for Environment and Energy, 41 pp. Report No. 197 (in Danish). http://dce2.au.dk/pub/SR197.pdf

Miner, J. R., F. J. Humenik, J. M. Rice, D. M. C. Rashash, C. Williams, and W. Robarge. 2003. Evaluation of a permeable, $5 \mathrm{~cm}$ thick, polyethylene foam lagoon cover. Trans. ASAE 46:1421-1426.

Misselbrook, T., J. Hunt, F. Perazzolo, and G. Provolo. 2016. Greenhouse gas and ammonia emissions from slurry storage: Impacts of temperature and potential mitigation through covering (pig slurry) or acidification (cattle slurry). J. Environ. Qual. 45:1520-1530.

Misselbrook, T. H., S. K. E. Brookman, K. A. Smith, T. Cumby, A. G. Williams, and D. F. McCrory. 2005c. Crusting of stored dairy slurry to abate ammonia emissions: Pilot-scale studies. J. Environ. Qual. 34:411-419.

Misselbrook, T. H., J. M. Powell, G. A. Broderick, and J. H. Grabber. 2005a. Dietary manipulation in dairy cattle: Laboratory experiments to assess the influence on ammonia emissions. J. Dairy Sci. $88: 1765-1777$.

Misselbrook, T. H., D. Scholefield, and R. Parkinson. 2005b. Using time domain reflectometry to characterize cattle and pig slurry infiltration into soil. Soil Use Manage. 21:167-172.

Møller, H. B., S. G. Sommer, and B. K. Ahring. 2002. Separation efficiency and particle size distribution in relation to manure type and storage conditions. Bioresour. Technol. 85:189-196.

Møller, H. B., S. G. Sommer, and B. K. Ahring. 2004. Biological degradation and greenhouse gas emissions during pre-storage of liquid animal manure. J. Environ. Qual. 33:27-36.

Myhre, G., D. Shindell, F.-M. Bréon, W. Collins, J. Fuglestvedt, J. Huang, D. Koch, J.-F. Lamarque, D. Lee, B. Mendoza, T. Nakajima, A. Robock, G. Stephens, T. Takemura, and H. Zhang. 2013. Anthropogenic and Natural Radiative Forcing. In: Climate Change 2013: The Physical Science Basis. Contribution of Working Group I to the Fifth Assessment Report of the Intergovernmental Panel on Climate Change. T. F. Stocker, D. Qin, G.-K. Plattner, M. Tignor, S. K. Allen, J. Boschung, A. Nauels, Y. Xia, V. Bex, and P. M. Midgley, ed. Cambridge University Press, Cambridge, UK.
Nielsen, O.-K., M. S. Plejdrup, M. Winther, M. Nielsen, S. Gyldenkærne, M. H. Mikkelsen, R. Albrektsen, M. Thomsen, K. Hjelgaard, P. Fauser, H. G. Bruun, V. K. Johannsen, T. Nord-Larsen, L. Vesterdal, I. Callesen, E. Schou, K. Suadicani, E. Rasmussen, S. B. Petersen, L. Baunbæk, and M. G. Hansen. 2016. Denmark's National Inventory Report 2015 and 2016. Emission Inventories 1990-2014. Submitted under the United Nations Framework Convention on Climate Change and the Kyoto Protocol. Aarhus University, DCE -Danish Centre for Environment and Energy. Scientific Report from DCE-Danish Centre for Environment and Energy. http://dce2.au.dk/pub/SR189.pdf.

Nielsen, T. H., and N. P. Revsbech. 1994. Diffusion chamber for nitrogen-15 determination of coupled nitrification-denitrification around soil-manure interfaces. Soil Sci. Soc. Am. J. 58:795-800.

Oenema, O., J. Salomez, C. Branquinho, M. Budnakova, P. Cermak, P. Geupel, P. Johnes, C. Tomkins, T. Spranger, J. W. Erisman, C. Palliere, L. Maene, R. Alonso, R. Maas, J. Magid, M. A. Sutton, and H. van Grinsven. 2011. Developing integrated approaches to nitrogen management. Pages 541-550 in European Nitrogen Assessment. M. A. Sutton, C. M. Howard, J. W. Erisman, G. Billen, A. Bleeker, P. Grennfelt, H. van Grinsven, and B. Grizzetti, ed. Cambridge University Press, UK. http://centaur.reading.ac.uk/ $20872 /$

Owen, J. J., and W. L. Silver. 2015. Greenhouse gas emissions from dairy manure management: A review of field-based studies. Glob. Change Biol. 21:550-565.

Patni, N. K., and P. Y. Jui. 1987. Changes in solids and carbon content of dairy-cattle slurry in farm tanks. Biol. Wastes 20:11-34.

Petersen, S. O., B. Amon, and A. Gattinger. 2005. Methane oxidation in slurry storage surface crusts. J. Environ. Qual. 34:455-461.

Petersen, S. O., A. J. Andersen, and J. Eriksen. 2012. Effects of slurry acidification on ammonia and methane emission during storage. J. Environ. Qual. 41:88-94.

Petersen, S. O., M. Blanchard, D. Chadwick, A. del Prado, N. Edouard, J. Mosquera, and S. G. Sommer. 2013a. Manure management for greenhouse gas mitigation. Animal 7:266-282.

Petersen, S. O., N. Dorno, S. Lindholst, A. Feilberg, and J. Eriksen. 2013b. Emissions of $\mathrm{CH}_{4}, \mathrm{~N}_{2} \mathrm{O}, \mathrm{NH}_{3}$ and odorants from pig slurry during winter and summer storage. Nutr. Cycl. Agroecosyst. 95:103-113.

Petersen, S. O., and D. N. Miller. 2006. Greenhouse gas mitigation by livestock waste storage and lagoon covers. J. Sci. Food Agric. 86:1407-1411.

Petersen, S. O., T. H. Nielsen, Å. Frostegård, and T. Olesen. 1996. Oxygen uptake, carbon metabolism, and denitrification associated with manure hot-spots. Soil Biol. Biochem. 28:341-349.

Petersen, S. O., H. H. Nissen, I. Lund, and P. Ambus. 2003. Redistribution of slurry in soil as influenced by organic matter content and injection method. J. Environ. Qual. 32:2399-2409.

Petersen, S. O., A. B. Olsen, L. Elsgaard, J. M. Triolo, and S. G. Sommer. 2016. Estimation of methane emissions from slurry pits under pig and cattle confinements. PLoS One 11:e0160968.

Petersen, S. O., S. G. Sommer, O. Aaes, and K. Søegaard. 1998. Ammonia losses from urine and dung of grazing cattle: Effect of $\mathrm{N}$ intake. Atmos. Environ. 32:295-300.

Philibert, A., C. Loyce, and D. Makowski. 2012. Quantifying uncertainties in $\mathrm{N}_{2} \mathrm{O}$ emission due to $\mathrm{N}$ fertilizer application in cultivated areas. PLoS One 7:e50950. https://doi.org/10.1371/journal .pone.0050950.

Powell, J. M., and C. A. Rotz. 2015. Measures of nitrogen use efficiency and nitrogen loss from dairy production systems. J. Environ. Qual. 44:336-344.

Prism Climate Group. 2017. Prism Climate Data. Accessed Oct. 31, 2017. http://www.prism.oregonstate.edu/normals/.

Qiao, C., L. Liu, S. Hu, J. E. Compton, T. L. Greaver, and Q. Li. 2015. How inhibiting nitrification affects nitrogen cycle and reduces environmental impacts of anthropogenic nitrogen input. Glob. Change Biol. 21:1249-1257.

Rahman, S., Y. Chen, K. Buckley, and W. Akinremi. 2004. Slurry distribution in soil as influenced by slurry application micro-rate and injection tool type. Biosyst. Eng. 89:495-504. 
Schils, R., J. E. Olesen, A. del Prado, and J. F. Soussana. 2007. A review of farm level modelling approaches for mitigating greenhouse gas emissions from ruminant livestock systems. Livest. Sci. $112: 240-251$.

Schils, R. L. M., A. Verhagen, H. F. M. Aarts, P. J. Kuikman, and B. J. Sebek. 2006. Effect of improved nitrogen management on greenhouse gas emissions from intensive dairy systems in the Netherlands. Glob. Change Biol. 12:382-391.

Shcherbak, I., N. Millar, and G. P. Robertson. 2014. Global metaanalysis of the nonlinear response of soil nitrous oxide $\left(\mathrm{N}_{2} \mathrm{O}\right)$ emissions to fertilizer nitrogen. Proc. Natl. Acad. Sci. USA 111:9199-9204.

Sommer, S. G., B. T. Christensen, N. E. Nielsen, and J. K. Schjorring. 1993. Ammonia volatilization during storage of cattle and pig slurry-Effect of surface cover. J. Agric. Sci. 121:63-71.

Sommer, S. G., and S. Husted. 1995. The chemical buffer system in raw and digested animal slurry. J. Agric. Sci. Camb. 124:45-53.

Sommer, S. G., J. E. Olesen, S. O. Petersen, M. R. Weisbjerg, L. Valli, L. Rodhe, and F. Béline. 2009. Region-specific assessment of greenhouse gas mitigation with different manure management strategies in four agroecological zones. Glob. Change Biol. 15:2825-2837.

Sommer, S. G., S. O. Petersen, and H. B. Møller. 2004. Algorithms for calculating methane and nitrous oxide emissions from manure management. Nutr. Cycl. Agroecosyst. 69:143-154.

Sommer, S. G., S. O. Petersen, and H. T. Søegaard. 2000. Greenhouse gas emission from stored livestock slurry. J. Environ. Qual. 29:744-750.

Sommer, S. G., S. O. Petersen, P. Sørensen, H. D. Poulsen, and H. B Møller. 2007. Methane and carbon dioxide emissions and nitrogen turnover during liquid manure storage. Nutr. Cycl. Agroecosyst. $78: 27-36$.

Sørensen, C. A. G., S. G. Sommer, D. Bochtis, and A. Rotz. 2013 Technologies and logistics for handling, transport and distribution of animal manures. Pages 211-234 in Animal Manure Recycling. S. G. Sommer, M. L. Christensen, T. Schmidt, and L. S. Jensen, ed. 1st ed. J. Wiley \& Sons Ltd., Chichester, UK.

Stehfest, E., and L. Bouwman. 2006. $\mathrm{N}_{2} \mathrm{O}$ and $\mathrm{NO}$ emission from agricultural fields and soils under natural vegetation: Summarizing available measurement data and modeling of global annual emissions. Nutr. Cycl. Agroecosyst. 74:207-228

Subbarao, G. V., O. Ito, K. L. Sahrawat, W. L. Berry, K. Nakahara, T. Ishikawa, T. Watanabe, K. Suenaga, M. Rondon, and I. M. Rao. 2007. Scope and strategies for regulation of nitrification in agricultural systems-Challenges and opportunities. Crit. Rev. Plant Sci. 25:303-335.

Thoma, G., J. Popp, D. Nutter, D. Shonnard, R. Ulrich, M. Matlock, D. S. Kim, Z. Neiderman, N. Kemper, C. East, and F. Adom. 2013a. Greenhouse gas emissions from milk production and con- sumption in the United States: A cradle-to-grave life cycle assessment circa 2008. Int. Dairy J. 31:S3-S14.

Thoma, G., J. Popp, D. Shonnard, D. Nutter, M. Matlock, R. Ulrich, W. Kellogg, D. S. Kim, Z. Neiderman, N. Kemper, F. Adom, and C. East. 2013b. Regional analysis of greenhouse gas emissions from USA dairy farms: A cradle to farm-gate assessment of the American dairy industry circa 2008. Int. Dairy J. 31:S29-S40.

Turnquist, A., J. Foltz, and C. Roth. 2006. Manure Management on Wisconsin Farms. PATS Res. Rep. No. 15.

Vadas, P. A. 2006. Distribution of phosphorus in manure slurry and its infiltration after application to soils. J. Environ. Qual. 35:542-547.

VanderZaag, A. C., J. D. MacDonald, L. Evans, X. P. C. Vergé, and R. L. Desjardins. 2013. Towards an inventory of methane emissions from manure management that is responsive to changes on Canadian farms. Environ. Res. Lett. 8:035008-035013.

Venterea, R. T., A. D. Halvorson, N. Kitchen, M. A. Liebig, M. A Cavigelli, S. J. Del Grosso, P. P. Motavalli, K. A. Nelson, K. A. Spokas, B. P. Singh, C. E. Stewart, A. Ranaivoson, J. Strock, and H. Collins. 2012. Challenges and opportunities for mitigating nitrous oxide emissions from fertilized cropping systems. Front. Ecol. Environ. 10:562-570.

Viguria, M., D. M. López, H. Arriaga, and P. Merino. 2015. Ammonia and greenhouse gases emissions from on-farm stored pig slurry. Water Air Soil Pollut. 226:285-292.

Webb, J., S. G. Sommer, T. Kupper, K. Groenestein, N. J. Huthings, B. Eurich-Menden, L. Rodhe, T. M. Misselbrook, and B. Amon. 2011. Emissions of ammonia, nitrous oxide and methane during the management of solid manures-A review. Sust. Agric. Rev. 8:67-107.

Weiske, A., A. Vabitsch, J. E. Olesen, K. Schelde, J. Michel, R. Friedrich, and M. Kaltschmitt. 2006. Mitigation of greenhouse gas emissions in European conventional and organic dairy farming. Agric. Ecosyst. Environ. 112:221-232

Wightman, J. L., and P. B. Woodbury. 2016. New York dairy manure management greenhouse gas emissions and mitigation costs (1992-2022). J. Environ. Qual. 45:266-275.

Wood, J. D., R. J. Gordon, C. Wagner-Riddle, K. E. Dunfield, and A Madani. 2012. Relationships between dairy slurry total solids, gas emissions, and surface crusts. J. Environ. Qual. 41:694-704.

Yiridoe, E. K., R. Gordon, and B. B. Brown. 2009. Nonmarket cobenefits and economic feasibility of on-farm biogas energy production. Energy Policy 37:1170-1179.

Zdanowicz, M., J. A. Shelford, C. B. Tucker, D. M. Weary, and M. A. G. von Keyserlingk. 2004. Bacterial populations on teat ends of dairy cows housed in free stalls and bedded with either sand or sawdust. J. Dairy Sci. 87:1694-1701. 